\title{
The Effect of Varying Magnetic Field Gradient on Combustion Dynamic
}

\author{
Vera Suzdalenko, Institute of Energy Systems and Environment, Riga Technical University, Maija Zake ${ }^{1}$, Inesa \\ Barmina $^{2},{ }^{1-2}$ Institute of Physics, University of Latvia, Martins Gedrovics, Institute of Energy Systems and \\ Environment, Riga Technical University
}

\begin{abstract}
The focus of the recent experimental research is to provide control of the combustion dynamics and complex measurements (flame temperature, heat production rate, and composition of polluting emissions) for pelletized wood biomass using a non-uniform magnetic field that produces magnetic force interacting with magnetic moment of paramagnetic oxygen. The experimental results have shown that a gradient magnetic field provides enhanced mixing of the flame compounds by increasing combustion efficiency and enhancing the burnout of volatiles.
\end{abstract}

Keywords - combustion dynamic, gradient magnetic field, wood pellets

\section{INTRODUCTION}

Worldwide, there is a growing interest in the use of biomass. There are different reasons for this: employment creation (biomass fuel plants create up to 20 times more jobs than coal and oil), political (reduction of energy dependency, observation of regulations) and environmental benefits (climate protection) [1] and [2]. At the same time, the utilization of biomass as an energy resource for the industrial energy production systems is limited because of the dissimilar structure, high moisture content and variations of the heating values for different biomass types, and determining variations of the combustion characteristics (flame dynamics, processes of heat/mass transfer and kinetics of the biomass chemical conversion) [3]. There are a lot of optimization possibilities for combustion characteristics (control of air preheating, combustion temperature, residence time of reactions, heat distribution, etc.) that influence emission levels and energy production efficiency in biomass heat plants [1]. One of the options to control the process of the combustion characteristics is the application of external forces (electrical, magnetic) to the flame reaction zone. The previous experimental study has shown [4] and [5] that application of the external forces allows control of the flame formation of the flame velocity, temperature and composition profiles, determining the flame shape and structure, but interpretation of the mechanism of the field effects on the flame dynamics requires further detailed analysis.

Over the past twenty years, researchers from Japan have found that the magnetic field can cause significant changes in diffusion flame behaviour, such as changes in emissions from the flames, changes in flame shape and size and the extinction points [6], [7] and [8]. The complex experimental research of the magnetic field effects on the swirling flame flow dynamics during biomass combustion that is carried out in the Institute of Physics, University of Latvia [4] and [5] indicate that application of the gradient magnetic field to the bottom part of the flame reaction zone can be used to provide the enhanced mixing of the flame species with a radial expansion of the inner recirculation zone, increasing combustion efficiency and burnout of the volatiles.

The motivation of the present study is to provide a detailed study of the mechanism of the gradient magnetic field on the swirling flame dynamics by varying the magnetic field induction $(B)$ and the external force $(F)$ that is applied at the bottom part of the combustor.

\section{II.LITERATURE REVIEW}

Michael Faraday was the first who attributed the magnetic field effect on the flame to the presence of charged particles in the flame. Later Von Engel and Cozens showed that the magnetic field effect on the behaviour of the flame could be attributed to the field effect on diamagnetic flame gases in the paramagnetic atmosphere [6] and [9]. The magnetic field affects fluids that can exhibit paramagnetic and diamagnetic behaviour. Oxygen $\left(\mathrm{O}_{2}\right)$ and air are paramagnetic flame species. These are drawn by the gradient magnetic force towards higher magnetic field strength. The examples of diamagnetic flame species are nitrogen $\left(\mathrm{N}_{2}\right)$, carbon monoxide and dioxide $\left(\mathrm{CO}, \mathrm{CO}_{2}\right)$, hydrogen $\left(\mathrm{H}_{2}\right)$ etc. Unlike paramagnetic flame species, diamagnetic are repelled by stronger magnetic fields [9] and [10]. These behaviours of paramagnetic and diamagnetic flame species could be explained by magnetic susceptibility $(\chi)$ (it is the measure of the degree to which a substance may be magnetized). The susceptibility of paramagnetic oxygen is higher than the susceptibility of diamagnetic flame species: $\chi_{\mathrm{O} 2} \approx 10^{-6}$ and $\chi \approx$ $10^{-9}$ respectively [7].

When the magnetic field is applied, the magnetic force acting on the flame species can be expressed with linear dependence on the mass density and magnetic susceptibility of chemical species $i$ and square dependence on the gradient of the magnetic flux density:

$$
F_{i}=\left(\frac{1}{2} \mu_{0}\right) \rho \mathrm{Y}_{i} \chi_{i} \nabla\left(B^{2}\right)
$$

$F i$ - magnetic force $\left(\mathrm{N} / \mathrm{m}^{3}\right)$,

$\mu_{o}-$ magnetic permeability $(\mathrm{H} / \mathrm{m})$,

$\rho$ - mass density $\left(\mathrm{kg} / \mathrm{m}^{3}\right)$,

$\chi_{i}-$ magnetic susceptibility $\left(\mathrm{m}^{3} / \mathrm{kg}\right)$, 
$Y_{i}-$ chemical species of mass fraction,

$\nabla\left(B^{2}\right)$ - the gradient of the square magnetic flux density $\left(\mathrm{T}^{2} / \mathrm{m}\right)[11]$ and [12].

Diamagnetic species that have no unpaired electrons generally have a negative value of $\chi_{i}$, while paramagnetic species with unpaired electrons have the positive value of $\chi_{i}$. The magnetic susceptibility of paramagnetic oxygen decreases when temperature increases. In accordance with Curries law:

$$
\chi_{i}=\frac{C}{T}
$$

$\mathrm{C}$ - the Currie constant.

$\mathrm{T}$ - temperature.

In accordance with (2), the magnetic field effect on the flame is influenced by local variations of the flame composition and temperature, determining the local variations of the Currie constant and magnetic susceptibility of the paramagnetic flame oxygen. Moreover, the magnetic field effect also determines the local variations of the flame composition and temperature across the flame reaction zone.

\section{EXPERIMENTAL SET-UP}

An experimental set-up has been designed, which allows the study of the axial magnetic field gradient effect on the swirling flame formation and combustion volatiles that are released during wood pellets gasification. A sketch of pilot scale set-up for the experimental study is presented in Fig. 1.

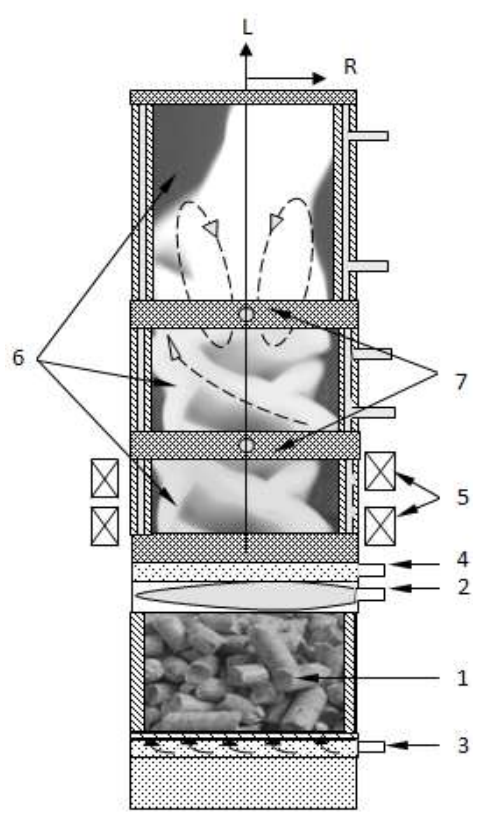

Fig. 1. Pilot scale-up: 1 - biomass gasifier, 2 - propane flame nozzle, 3 primary air supply, 4 - secondary air swirl nozzle, 5 - coils of electromagnet, 6 - water-cooled combustor, 7 - diagnostic sections.

The experimental set-up consists of a biomass gasifier (1), where different types of biomass pellets could be gasified. The propane flame flow (2) is used to provide additional heat energy supply into the pelletized biomass layer (250-300 grams) at an average rate of $1 \mathrm{~kJ} / \mathrm{s}$ to initiate the thermal decomposition of the biomass. Primary air (3) is supplied below the pelletized biomass layer at the rate of $38 \mathrm{l} / \mathrm{min}$ to provide biomass gasification; the secondary air (4) is supplied above the biomass layer at the rate $651 / \mathrm{min}$ to provide combustion of the volatiles. The secondary air supply provides a relatively high swirl intensity with an average swirl number $\mathrm{S} \approx 0.88-1$, determining the formation of the inner recirculation zone at the bottom part of the combustor. The combustion of volatiles is developing downstream of the water-cooled combustor (6) that is composed of three watercooled sections, separated by diagnostic sections (7). The diameter (D) of the combustor is $60 \mathrm{~mm}$, total length (L) 240 $\mathrm{mm}$.

To provide the experimental study of the magnetic field effect on the combustion dynamics of the volatiles, two electromagnet coils (5) are used to produce the axial magnetic field gradient $(d B / d z)$ in a range from $0.03 \mathrm{~T} / \mathrm{m}$ up to $0.2 \mathrm{~T} / \mathrm{m}$. For the given field configuration, the magnetic force acts in a direction reverse to the axial velocity of the swirling flame flow at a nearly constant magnetic induction across the flame radius $(d B / d r=0)$.

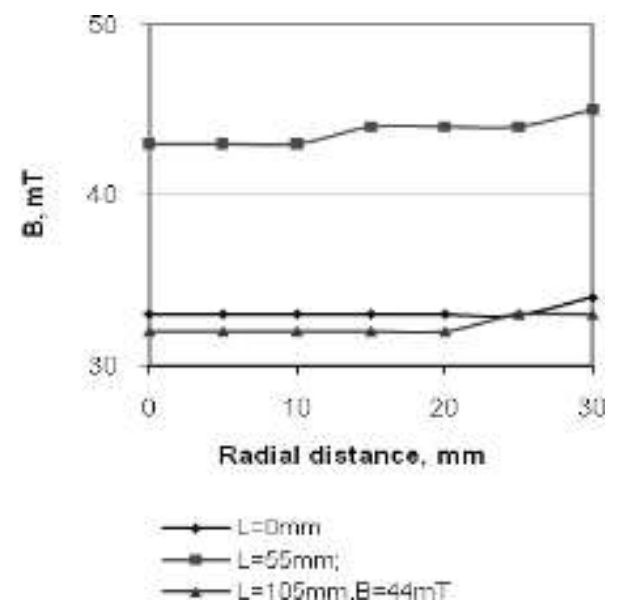

Fig. 2. The radial distribution of the magnetic field induction in the flame reaction zone at different distances from the bottom part of the electromagnet.

Figure 2 shows the radial distribution of the magnetic field induction in the flame reaction zone at different distances from the bottom part of the electromagnets $(0-105 \mathrm{~mm})$, determining a negligible effect of radial magnetic field gradient on the mass transfer of paramagnetic oxygen.

The investigations of the axial magnetic field gradient effect on the formation of the flame velocity, the combustion of volatiles and composition profiles are carried out by varying the peak magnetic field induction at the bottom part of combustor in a range from 0.01 up to $0.05 \mathrm{~T}$ with correlating variations of the magnetic field distribution downstream the flame reaction zone and magnetic field force acting on the flame reaction zone (Fig. 3). 


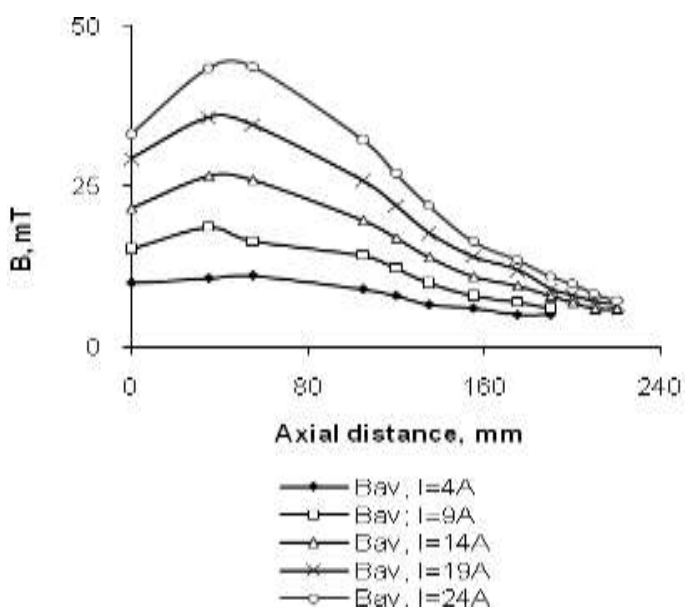

Fig. 3. The axial distribution of the magnetic field induction in the flame reaction zone at different values of current in the coils of electromagnets.

For the local measurements of the flame velocity, temperature and composition profiles of the diagnostic sections with orifices (7a) are used by inserting the diagnostic tools (Pitot tube, thermocouples, gas sampling probe) into the flame reaction zone. The flame velocity and composition was measured using the gas analyzer Testo-350 XL. The on-line measurements of the flame temperature and heat production rate downstream of the combustor are carried out using the date recording plate $\mathrm{PC}-20$. All measurements are carried out with a time interval of 1 second, determining the local average values from 10 measurements. The duration of experiments is about 2400 seconds.

\section{RESULTS AND DISCUSSION}

The local measurements of the formation of the swirling flame velocity field have shown that the gradient magnetic field enhances the reverse axial motion of the paramagnetic oxygen upstream to the wood pellets layer providing significant variations of swirl flame dynamics and the formation of the flame velocity field (Fig. 4, 5).

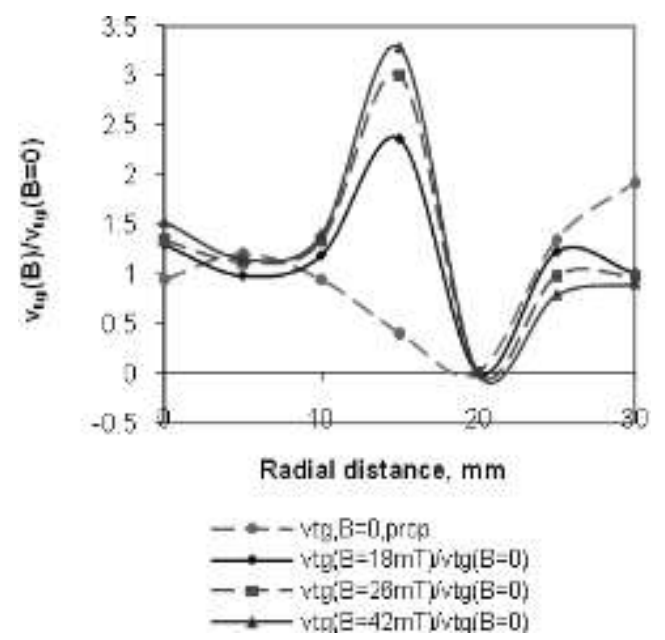

Fig. 4. The effect of the magnetic field gradient on the tangential flame velocity profiles.

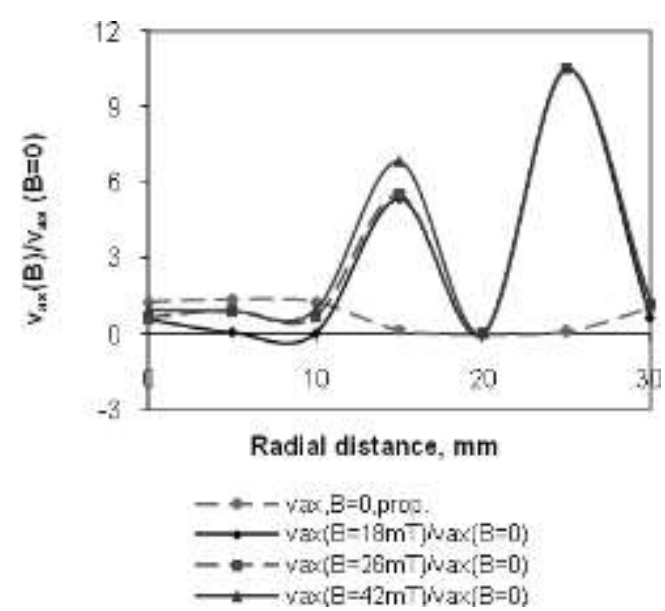

Fig. 5. The effect of the magnetic field gradient on the axial flame velocity profiles.

As follows from Figure 5, the gradient magnetic field slows down the axial flame velocity by enhancing the reverse axial mass transfer of paramagnetic oxygen with field-enhanced recirculation and mixing of the flame compounds with direct influence on the formation of the heat production rate, as well as flame temperature and composition profiles (Fig. 6-8).

The experimental study of the field induced variations of the flame temperature profiles at the primary stage of the swirl flame formation have shown that the field-recirculation promotes a decrease of the temperature close to the flame axis (up to 10-26\%), increasing the temperature along the outside part of the flame reaction zone, indicating the fieldenhanced gasification and combustion of the volatiles with a radial expansion of the flame reaction zone (Fig. 6) and correlating increase of the rate of heat energy production downstream of the water-cooled combustor (Fig. 7).

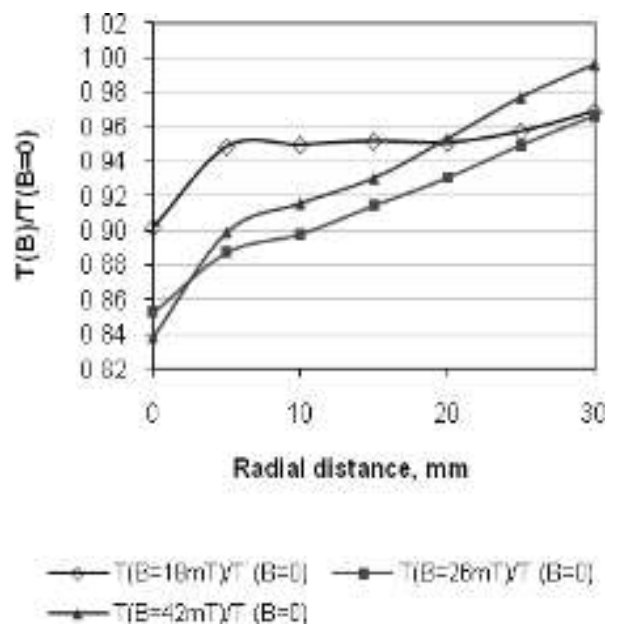

Fig. 6. The effect of the varying the peak magnetic field on the flame temperature profile. 


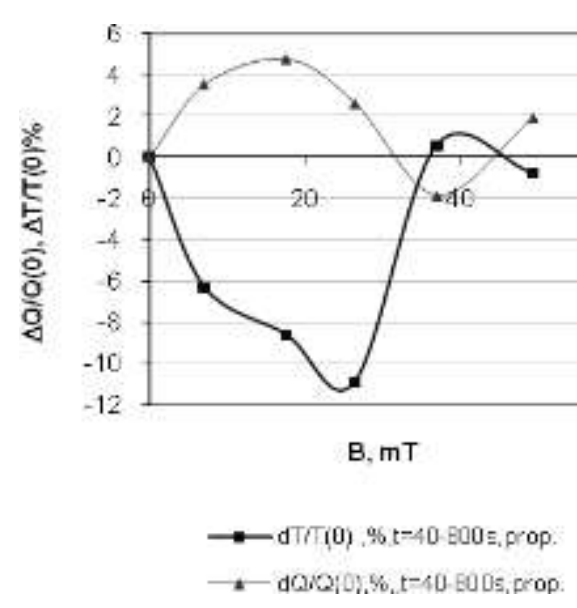

Fig. 7. The local field-induced variations of the flame temperature and heat production rate during combustion of wood pellets by varying the magnetic field strenght.

As follows from Figure 7, the maximum value of the fieldinduced heat production rate with minimum value of the temperature close to the flame axis is observed at $\mathrm{B} \approx 20$ $30 \mathrm{mT}$.

The field-enhanced gasification and combustion of the volatiles shows influence on the formation of the flame composition profiles above the recirculation zone, close to the flame axis $(\mathrm{R}=0)$, indicating the field-induced increase of the mass fraction of $\mathrm{CO}$ and $\mathrm{CO}_{2}$ up to the peak value with correlating decrease of the air excess in the products to the minimum value at $\mathrm{B} \approx 20 \mathrm{mT}$.
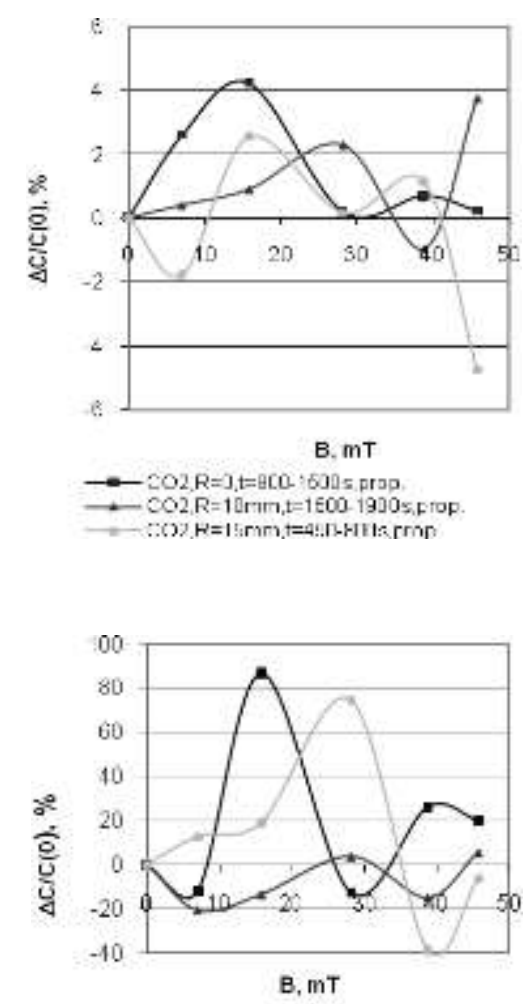

$\rightarrow-\operatorname{Cor}=0,:=600 \cdot \operatorname{sons}, 0,00$.

$\rightarrow C C R=10 \mathrm{rm}, t=1500-13003$ arop

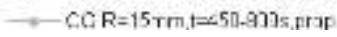
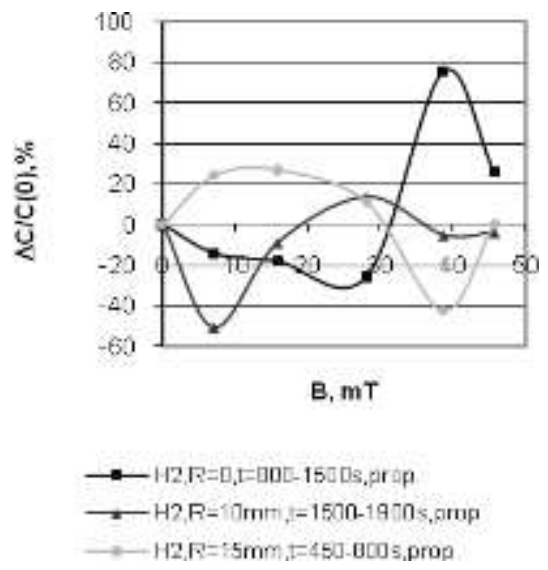

Fig. 8. The local field-induced variations of composition $\left(\mathrm{CO}_{2}, \mathrm{CO}, \mathrm{H}_{2}\right)$ of wood pellets by varying the magnetic field gradient.

At a relatively high magnetic field strength $(\mathrm{B}>18 \mathrm{mT})$, the increasing swirling flow velocity downstream of the combustor decreases the residence time of chemical reactions, combustion efficiency, volume fraction of $\mathrm{CO}_{2}$, while increasing the mass fraction of unburned flame species ( $\mathrm{CO}$, $\mathrm{H}_{2}$ ) and air excess in the products (Fig. 8, 9).

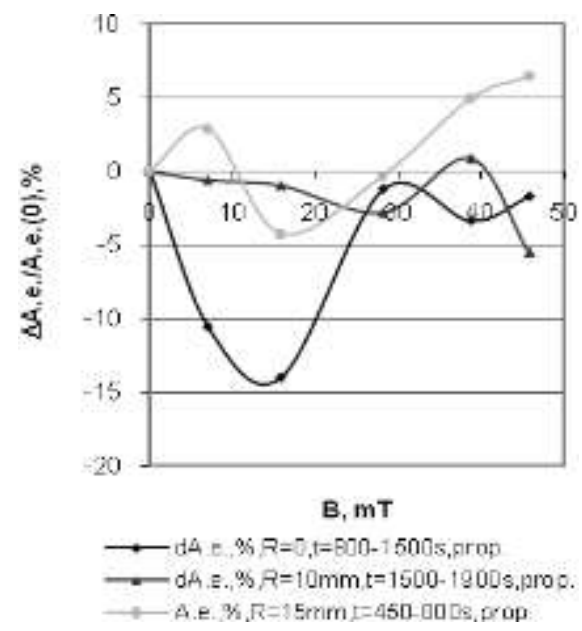

Fig. 9. The air excess variations by changing magnetic fiel gradient.

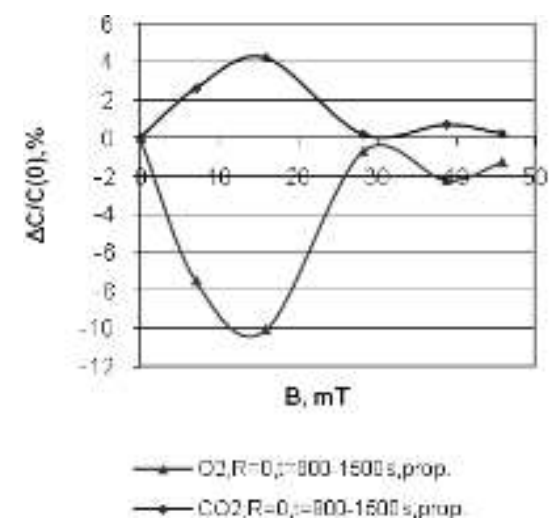

Fig. 10. The variations of the magnetic field effect on $\mathrm{O}_{2}$ and $\mathrm{CO}_{2}$ particles concentration in the centre of the channel. 
A relatively weak magnetic field $(\mathrm{B}<20 \mathrm{mT})$ causes a decrease of oxygen fraction, in contrast to $\mathrm{CO}_{2}$, the concentration of which increased (Fig. 10). These variations could be described with magnetic properties of these elements - $\mathrm{O}_{2}$ is paramagnetic, $\mathrm{CO}_{2}$ is diamagnetic, which under magnetic pressure move out or into the centre of the channel respectively. However, considering air excess value at the same magnetic field gradient value at $\mathrm{R}=15 \mathrm{~mm}$, it could be concluded that a weak magnetic force $(\mathrm{B}<20 \mathrm{mT}$ ) provides an enhanced combustion of the volatiles.

\section{V.CONCLUSIONS}

The following conclusions have been drawn from the experimental study of the magnetic field gradient effect on the formation of the flame velocity, the combustion of volatiles and composition profiles:

- increasing the gradient magnetic field induction up to $42 \mathrm{mT}$ enhances the recirculation with field-enhanced reverse axial mass transfer of paramagnetic oxygen up to the surface of wood layer by enhancing wood fuel gasification, and with the enhanced mixing of the flame compounds and burnout of volatiles that increases the efficiency of combustion and rate of heat production;

- at relatively high magnetic field strength $(\mathrm{B}>18 \mathrm{mT}$ ), the increasing swirling flow velocity downstream of the combustor decreases the residence time of chemical reactions, combustion efficiency, volume fraction of $\mathrm{CO}_{2}$, while increases the mass fraction of unburned flame species $\left(\mathrm{CO}, \mathrm{H}_{2}\right)$.

\section{REFERENCES}

1. Van Loo, S. The Handbook of Biomass Combustion \& Co-firing. UK: CPI Antony Rowe, 2008. 442 p.

2. Nussbaumer, T. Combustion and Co-combustion of Biomass: Fundamentals, Technologies, and Primary Measures for Emission Reduction. Energy \& Fuels, 2003, N 17, p. 1510-1521.

3. Arena, U., Zaccariello, L., Mastellone, M. Gasification of natural and waste biomass in a pilot scale fluidized bed reactor. Combustion Science and Technology, 2010, p.625-639.

4. Barmina, I., Zaķe, M., Krishko, V., Gedrovics, M. Modification of wood pellets and propane co-firing in a magnetic field. Environmental and Climate Technologies, 2010, ser.13, Nr.4, p. 1621.

5. Zake M., Barmina I., Buvinieks I., Krishko V. Magnetic field Control of Combustion Dynamics of the Swirling Flame Flow. Magnetohydrodynamics, 2009, Nr.2, p. 171-186.

6. Calvert, M.E., Baker, J., Saito, VanderWal, R.L. An Analytical Model for Non-Uniform Magnetic Field Effects on TwoDimensional Laminar Jet Diffusion Flames. In: Sixth International Microgravity Combustion Workshop, NASA Glenn Research Center, Cleveland, May 22-24, 2001, p. 381-384.

7. Nagaraju, K. Study of the Effects of Magnetic Field on the Properties of Combustion Synthesized Iron Oxide Nanoparticles. Mg. thesis, India: Jawaharlal Nehru Technological University, 2005, $133 \mathrm{p}$.

8. Wakayama, N.I. Behaviour of Gas Flow under Gradient Magnetic Fields. Journal of Applied Physics, 1991, p. 2734-2736.

9. Swaminathan, S. Effect of Magnetic Field on Micro Flames. Mg. thesis, Louisiana: Louisiana State University, 2005, 125 p.

10. Baker, J., Calvert, M.E., Saito, K., VanderWal, R. Holographic Interferometry and Laminar jet Diffusion Flames in the Presence of Non-Uniform Magnetic Fields. In: Sixth International Microgravity
Combustion Workshop, NASA Glenn Research Center, Cleveland, May 22-24, 2001, p. 361-364

11. Gilard V., Gillon P., Blanchard C.J.N. Effects of a Magnetic Field on the Stabilization of A Lifted Diffusion Flame: Proceeding of the European Combustion Meeting, 2009 - [Accessed 08.08.2011.]. Available: http://www.combustion.org.uk/ECM_2009/P810266.pdf

12. Yamada, E., Shinoda, M., Yamashita, H., Kitagawa, K. Experimental and numerical analyses of magnetic effect on $\mathrm{OH}$ radical distribution in a hydrogen-oxygen diffusion flame. Combustion and Flame, 2003, N 135, p. 365-379.

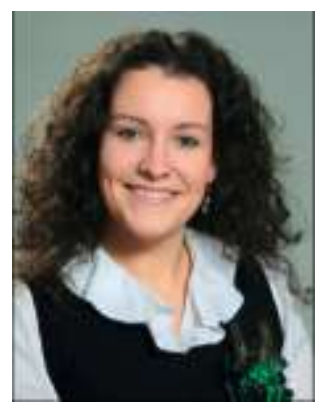

Vera Suzdalenko, Mg.sc., Riga Technical University, Institute of Energy System and Environment. Vera Suzdalenko has been a researcher of Institute of energy system and environment since 2010. She has Master degree (2009) and she is $\mathrm{PhD}$ student of RTU Institute of Energy System and Environment. The main research area is investigation of renewable and fossil fuel co-firing and magnetic field effect on swirling combustion. Vera Suzdalenko participated in local and international conferences. She is a co-author of 11 scientific papers.

Address: Kronvalda blvd. 1, LV-1010, Riga, Latvia

Phone: +371 29719715

E-mail: Vera.Suzdalenko@rtu.lv

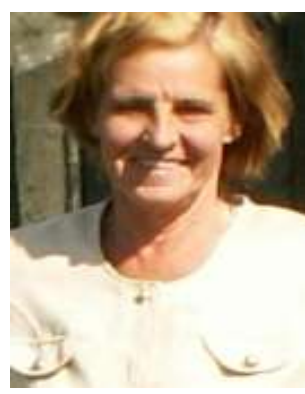

Maija Zake, Dr.phys., University of Latvia, Institute of Physics. Maija Zake has been a leading researcher of Heat and mass transfer laboratory of Institute of Physics since 1991. $\mathrm{PhD}$ promotion - thesis "Electrical conductivity of two phase and two component's system" (1992). The main research areas - gasification and combustion of renewable fuels, co-firing of renewable with fossil fuels, external electric, magnetic and electromagnetic field effects on combustion of renewables.

Maija Zake is co-author of 220 papers and 2 monographs, since 2005 co-author of 18 scientific papers and co-author of 10 presentations in International conferences. Maija Zake is co-author of a patent "Boiler for co-firing of renewable with fossil fuel" (2005) and research leader of Latvian grants from 1991 up to 2006, coordinator of ERAF projects VPD1/ERAF/CFLA/05/APK/2.5.1./000001/001, 20062008 and Nr.2010/0241/2DP/2.1.1.1.0/10/APIA/VIAA/006,2010-2013. E-mail: mzfi@sal.lv

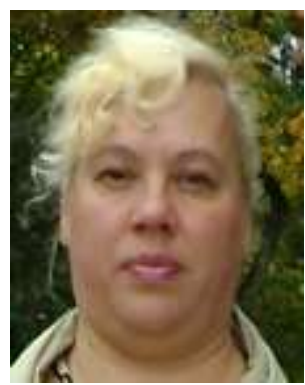

Inesa Barmina, Dr.sc.ing., University of Latvia, Institute of Physics. Inesa Barmina is a leading researcher of Heat and mass transfer laboratory of Institute of Physics, University of Latvia since 2004. $\mathrm{PhD}$ thesis "Investigation of external electrical field effects on swirling combustion" (2003). The main research area is experimental study of co-firing the renewable with fossil fuel and external (electric, magnetic, electromagnetic) field effects on swirling combustion. Since 2004 Inesa Barmina is leading researcher of Latvian grants and ERAF projects: VPD1/ERAF/CFLA/05/APK/2.5.1./ 000001/001, 2006-2008 and Nr.2010/0241/2DP/2.1.1.1.0/10/APIA/VIAA/ $006,2010-2013$. She is co-author of more than 60 scientific papers. She is co-author of 8 presentations in International conferences since 2005. Inesa Barmina is co-author of patent "Boiler for co-firing of renewable with fossil fuel" (2005).

E-mail: barmina@sal.lv 


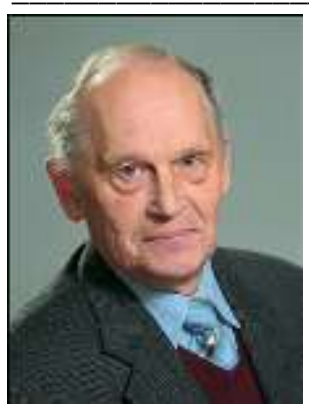

Martins Gedrovics, Dr.sc.ing., professor, Riga Technical University, Institute of Energy Systems and Environment. Professor Martins Gedrovics is working within the Faculty of Energy and Electrotechnics, Riga Technical University since 1970 . The main research area is combustion of biofuels. He has participated in different local and international projects related to energy and environment. $M$ Gedrovics is author of about 80 publications. M. Gedrovičs has Thermal Engineer Diploma (1967) and doctoral degree (1997).

E-mail: martins.gedrovics@rtu.lv

Vera Suzdaḷenko, Maija Zaķe, Inesa Barmina, Mārtiņš Gedroviěs. Magnētiskā lauka gradienta izmaiņas ietekme uz degšanas procesa dinamiku. Pasaulē ir liela interese par biomasas izmantošanu enerǵijas ražošanai, tomēr biomasas izmantošana siltumenerğijas un elektro enerǵijas ražošanā ir ierobežota, jo dažādas izcelsmes biomasai ir raksturīga neviendabīga struktūra, sastāvs, mitrums un zems enerḡêtiskais blīvums. Eksistē vairāki pan̄ēmieni (gaisa uzsildīšana pirms padeves, degšanas procesa temperatūra, reakcijas norises laiks, siltuma sadalījums utt.), ar kuru pielietošanas palīdzību var samazināt emisiju daudzumu un palielināt degšanas procesa efektivitāti. Pēdējos 20 gados pētnieki no Japānas atklājuši, ka magnētiskais lauks izraisa nozīmīgas izmainas liesmas uzvedībā: tiek mainīta forma un izmērs, kā arī emisijas. Pētījuma mērķis ir izpētî̀t, kā magnētiskā lauka gradienta izmaiņas ietekmē liesmas virpuḷplūsmas ātrumu un sastāva profilus, dedzinot koksnes granulas. LU Fizikas institūta laboratorijā ir izveidota eksperimentālā iekārta, kur tiek dedzinātas koksnes granulas un propāns. Apkārt iekārtai ir izveidots magnētiskais lauks ar divu elektromagnētu palīdzību. Eksperimentālo pētījumu rezultātā tika konstatēts, ka, palielinot magnētiskā lauka indukciju līdz 42 mT, tiek uzlabota paramagnētiskā skābekḷa recirkulācija virzienā uz gazificējamās koksnes granulu virsmu, uzlabojot kurināmā liesmas sastāvdaḷu sajaukšanos un gaistošo savienojumu degšanu, kas savukārt palielina degšanas procesa efektivitāti un siltumenerǵijas ražošanas ātrumu. Pie relatīvi liela magnēti skā lauka indukcijas (B > 18 mT) palielināts liesmas virpuḷplūsmas ātrums samazina ķīmisko reakciju norises laiku, degšanas efektivitāti, $\mathrm{CO}_{2}$ tilpuma daļu, savukārt palielinot nesadedzināto liesmas daḷiņu $\mathrm{CO}$ un $\mathrm{H}_{2}$ masas daḷu. 